\title{
Fatty acid composition of the estuarine Flexibacter sp. strain Inp: effect of salinity, temperature and carbon source for growth
}

\author{
P. INTRIAGo*† and G. D. Floodgate \\ School of Ocean Sciences, Marine Science Laboratories, Menai Bridge, Gwynedd LL59 5EY, UK
}

(Received 2 October 1990; revised 25 January 1991; accepted 6 March 1991)

\begin{abstract}
The total fatty acid content of the estuarine Flexibacter sp. strain Inp and the relative proportions of its constituent fatty acids were affected by growth temperature and salinity. Whilst both the proportion and concentration of the polyunsaturates were markedly stimulated by increases in salinity, the total amount of fatty acid per mg cell protein decreased. The highest concentration of fatty acid per $\mathrm{mg}$ cell protein did not coincide with the highest percentage of polyunsaturated fatty acids, which occurred when the bacterium was grown on glucose. The presence of an inverse relationship between C16:1w5 and C18:1w9 are regarded as evidence that two different pathways exist for the biosynthesis of unsaturated fatty acids in Flexibacter strain Inp.
\end{abstract}

\section{Introduction}

Changes in temperature, salt concentration and carbon source in the medium are known to produce variations in the membrane lipids of bacteria (Marr \& Ingraham, 1962; Okuyama et al., 1977; Kawagushi \& Seyama, 1984; Russell \& Kogut, 1985; Kates, 1986a; Rose, 1989). Variations in fatty acid composition due to changes in temperature and salinity differ between Gram-negative and Gram-positive bacteria. For example, lowering the growth temperature of the Gram-positive halotolerant Planococcus sp., results in increased amounts of branched and monounsaturated fatty acids (MUFAs), while the concentration of aC15:0 increases as the salt content is raised (Miller, 1985, 1986). In Deleya halophila, a moderately halophilic, Gram-negative bacterium, there is a decrease in MUFAs with a concomitant increase in cyclopropane fatty acids as the salt concentration in the medium is raised (Monteoliva-Sanchez et al., 1988).

Reports on the fatty acid composition of members of the genus Flexibacter vary. Fautz et al. (1979) and Poen et al. (1984) reported branched as well as hydroxy fatty acids to be the main components. Nichols et al. (1986), working with several species, reported monounsaturated and branched fatty acids as the most important groups,

† Present address: Aqualab, PO Box 5738, Guayaquil, Ecuador.

Abbreviations: FAME, fatty acid methyl ester; MUFA, monounsaturated fatty acid; PUFA, polyunsaturated fatty acid; p.p.t., parts per thousand (salinity). and Johns \& Perry (1977) reported the presence of high amounts of long chain polyunsaturated fatty acids (PUFAs) in $F$. polymorphus.

PUFAs have been considered to be absent from bacteria (Shaw, 1974). However, recent work on bacteria from the marine environment has indicated that PUFAs may be more widespread than thought hitherto. Delong \& Yayanos (1986) and Wirsen et al. (1987) examined a number of deep-sea bacteria and found significant amounts of PUFAs, as did Johns \& Perry (1977) working with the marine species $F$. polymorphus. More recently, Yazawa et al. (1988) showed that $1.6 \%$ of isolates from fish intestines produced $\mathrm{C} 20: 5 \mathrm{w} 3$; in one strain, which was similar to the genus Alteromonas, this compound comprised $36 \%$ of the total fatty acids. The ecological role played by PUFA-producing bacteria in the sea remains obscure, but it is possible that they contribute to the PUFA intake of larval forms including commercially important crustacean species.

The bacterium Flexibacter sp. strain Inp, used in this study, is widely distributed in the Ecuadorian shrimp ponds from which it was isolated. These ponds are subjected to wide variations in temperature and salinity. Flexibacter strain Inp is orange pigmented and forms filamentous threads with spreading growth on plates; gliding is not very active. It can utilize nitrate and glutamate as nitrogen sources and peptone can be used as both carbon and nitrogen source. It can degrade gelatin and starch, but not agar or alginate. It is sensitive to lauryl sulphate, does not survive in fresh water, but grows on sea water media, tolerating up to 120 p.p.t. salinity. It 
is catalase- and oxidase-positive. Reichenbach (1989), in the most-recent edition of Bergey's Manual of Systematic Bacteriology, suggests that marine Flexibacter-like strains should be considered as members of the genus Microscilla.

\section{Methods}

Culture techniques. Cultures were maintained at $25^{\circ} \mathrm{C}$ on ZoBell 2216-E solid medium (Oppenheimer \& ZoBell, 1952). Before starting each experiment a subculture, taken from a 1- or 2-weeks-old ZoBell culture plate, was suspended in the medium to be tested; with the exception of the carbon source, this medium consisted of $2 \mathrm{~g}$ ammonium sulphate, $0.2 \mathrm{~g}$ dipotassium hydrogen phosphate, $0.5 \mathrm{~g}$ yeast extract, $0.5 \mathrm{~g} \mathrm{Tris} / \mathrm{HCl}$ and $1 \mathrm{ml}$ of trace metal solution (Reichenbach \& Dworkin, 1981) in 1 litre of sea water of salinity 30 p.p.t., adjusted to $\mathrm{pH} 7 \cdot 6$. Cycloheximide $\left(0.1 \mathrm{~g} \mathrm{l}^{-1}\right)$ was used to inhibit growth of eukaryotes. Since sea water contains a considerable number of different ions, salinities are quoted in the oceanographic sense, as parts per thousand (p.p.t.) (Riley \& Chester, 1971). Salinities were measured with an inductive salinometer.

Temperature experiments. The temperatures tested were 18, 24 and $30^{\circ} \mathrm{C}$. Experiments were done in $250 \mathrm{ml}$ flasks with $50 \mathrm{ml}$ of culture medium and $5 \mathrm{ml}$ of inoculum. Cultures were bubbled with $200: 10 \mathrm{ml}$ of an air/nitrogen mixture $\mathrm{min}^{-1}$. The flasks were immersed within a water/bath controlled at the appropriate temperature.

Salinity relationships. Experiments were done using either starch or ZoBell 2216-E medium as carbon source, at $15,30,45$ and 60 p.p.t., or $30,45,60$ and 120 p.p.t., respectively. Cultures were bubbled with $100: 20 \mathrm{ml}$ of an air/nitrogen mixture $\mathrm{min}^{-1}$, and incubated at $24^{\circ} \mathrm{C}$ in a water-bath. Salinity was decreased by mixing the sea-water medium (salinity 30 p.p.t.) with distilled water, or increased by adding the mixture of marine salts described in Reichenbach and Dworkin (1981).

Inclusion of betaine $(10 \mathrm{mM})$ in the medium was necessary to obtain growth of strain Inp at high salinities (45, 60 and 120 p.p.t.). Betaine and related compounds are known to promote growth of bacteria in media of high osmotic strength (Le Rudulier \& Bouillard, 1983; Imhoff \& Rodriguez-Valera, 1984; Le Rudulier et al., 1984).

Carbon sources. A mixture of sterile air/nitrogen $(100: 20)$ was used to aerate the cultures. The salinity of the medium was 30 p.p.t. and the temperature ws $24^{\circ} \mathrm{C}$. Except for the carbon source and the exclusion of yeast extract, the medium used was as described above. The carbon sources and their concentrations were as follows: starch, glucose, lactose, gluconate and Casamino acids $\left(5.0 \mathrm{~g} \mathrm{l}^{-1}\right)$; glycerol $\left(3.9 \mathrm{ml} \mathrm{l}^{-1}\right)$; Tween $80\left(12.6 \mathrm{ml}^{-1}\right)$. Except for Casamino acids and Tween 80, these values were chosen to normalize the carbon:nitrogen ratio of the medium to $5: 1$. ZoBell $2216-\mathrm{E}$ medium diluted to half-strength $(1 / 2-Z o B e l l)$ by the addition of sea water was also used.

Cultures were harvested during the late exponential phase, which ranged from 25 to $50 \mathrm{~h}$ depending on temperature, salinity and the carbon source used, by centrifugation at $10000 \mathrm{~g}$ for $15 \mathrm{~min}$ at $10^{\circ} \mathrm{C}$; the bacteria were then washed once in $\mathrm{NaCl}(0.5 \mathrm{M})$ and centrifuged again. The bacterial pellet was resuspended in $10 \mathrm{ml}$ of potassium phosphate buffer (50 mM, pH 7.5) (White et al., 1979) and stored at $-20^{\circ} \mathrm{C}$.

Lipid extraction. Lipids were extracted by adding enough chloroform/methanol $(1: 2, \mathrm{v} / \mathrm{v})$ to a thawed cell pellet to obtain a single phase chloroform/methanol/phosphate buffer mixture $(1: 2: 0 \cdot 8$, by vol.). This extract was left at $4{ }^{\circ} \mathrm{C}$ overnight, then water and chloroform were added to form two separate phases (Bligh \& Dyer, 1959; White et al., 1979). The total cell fatty acids, present in the lower layer, were extracted using a technique based on that of Moss et al. (1974) and Larsson \& Odham (1984). The lipid exract was dried under a stream of nitrogen and then saponified with either $5 \%(\mathrm{w} / \mathrm{v}) \mathrm{NaOH}$ or $\mathrm{KOH}$ in $50 \%(\mathrm{v} / \mathrm{v})$ methanol at $100^{\circ} \mathrm{C}$ for $45 \mathrm{~min}$. The methanolysates were cooled, and adjusted to $\mathrm{pH} 2$ with $\mathrm{HCl}(6 \mathrm{M})$. Chloroform $(1 \mathrm{ml})$ was added and the mixture was shaken vigorously and allowed to separate into two phases. The upper phase was discarded and the lower fattyacid-containing phase was dried under a stream of nitrogen. The fatty acids were esterified with $2 \mathrm{ml} 10 \%(\mathrm{v} / \mathrm{v}) \mathrm{BCl}_{3}$ in methanol at $80^{\circ} \mathrm{C}$ for $10 \mathrm{~min}$. After cooling, the fatty acids methyl esters (FAMEs) were extracted by adding $1 \mathrm{ml}$ saturated $\mathrm{NaCl}$ and $2 \mathrm{ml}$ hexane/chloroform $(4: 1, v / v)$. The extract was evaporated under a stream of nitrogen, redissolved in chloroform and spotted on to a TLC plate (precoated silica gel 60, Merck) to separate FAMEs from other reaction products. The plates were developed for $90 \mathrm{~min}$ in a continuous elution tank using hexane/diethyl ether $(90: 10, \mathrm{v} / \mathrm{v})$ as the solvent system. FAMEs were located using iodine vapour and areas of silica gel containing FAMEs were scraped from the plates and the FAMEs dissolved in chloroform/methanol $(2: 1, \mathrm{v} / \mathrm{v})$. The solvent was evaporated to dryness and the FAMEs were redissolved in $200 \mu$ l hexane.

FAMEs were analysed using a Carlo Erba gas chromatograph (model Vega 6180) with on-column injection into a $30 \mathrm{~m} \times 0.25 \mathrm{~mm}$ i.d. DB225 fused silica column (J \& W Scientific) or an Econo-cap, Carbowax $30 \mathrm{~m} \times 0.25 \mathrm{~mm}$ i.d. capillary column (Alltech). Hydrogen was the carrier gas $\left(2.0 \mathrm{ml} \mathrm{min}^{-1}\right)$. The oven temperature was programmed to rise from 50 to $150^{\circ} \mathrm{C}$ at a ramp rate of 49.9 centrigrade degrees min-1 and then 3 centigrade degrees $\mathrm{min}^{-1}$ to $230^{\circ} \mathrm{C}$, and held for $10 \mathrm{~min}$. The temperature was $250^{\circ} \mathrm{C}$. Uniform response was assumed for all components. Quantification was based on comparison of peaks areas with an internal standard (C23:0). FAMEs were identified by comparison of their retention times with known standards. The identity of PUFAs was confirmed by GC/MS using a Finnigan gas chromatograph/mass spectrometer fitted with a $30 \mathrm{~m} \times 0.25 \mathrm{~mm}$ i.d. OV1 capillary column, and with helium as the carrier gas. Samples were injected in splitless mode at $180^{\circ} \mathrm{C}$. The oven temperature was programmed to rise from 60 to $280^{\circ} \mathrm{C}$ at a ramp rate of 6 centrigrade degrees $\min ^{-1}$. The electron impact ionization voltage was $70 \mathrm{eV}$. Hydrogenation was also used to confirm the presence of double bonds (Kates, 1986 b), whose position was determined by MS analysis of the Diels-Alder adducts, formed by reacting FAMEs with 5,5-dimethoxy1,2,3,4-tetrachlorocyclopentadiene (Aldrich) (Kidwell \& Bieman, 1982; Nichols et al., 1985).

Protein. Protein was determined by a modification of the method of Lowry, after extracting the cells in $\mathrm{NaOH}$ (1 M) (Hanson \& Phillips, 1981). Bovine serum albumin was the standard used.

Chemicals. All reagents used were analytical grade (Sigma and BDH). Solvents were from Rathburn.

Statistics. Analyses were done using the Minitab statistical package on a Vax mainframe computer.

\section{Results}

\section{Gas chromatography/mass spectrometry}

The mass spectra of commercial standards of linoleic and linolenic acid were found to be identical to that of the compounds found in Flexibacter strain Inp, and identified as linoleic and linolenic acids from their retention times. The ion fragments of both the C16:1w5 and 


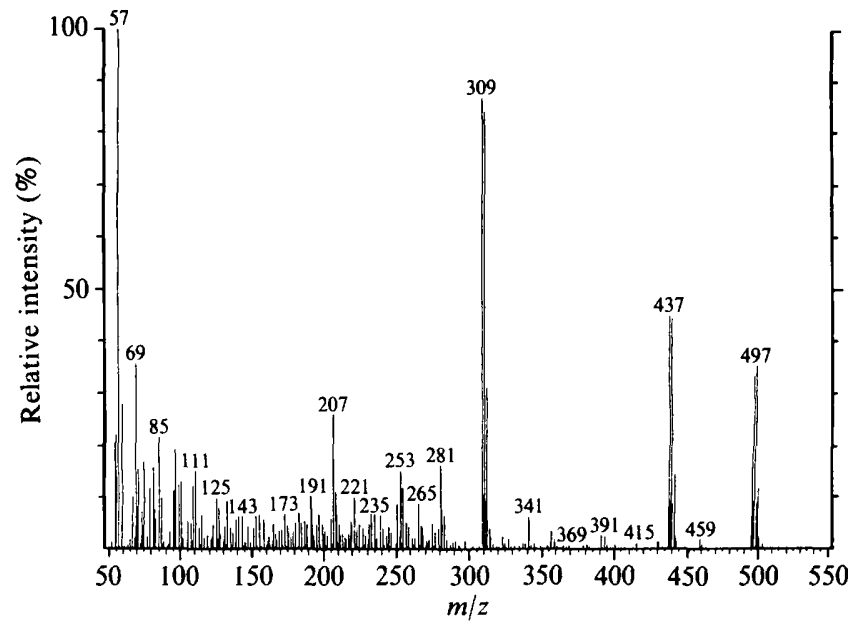

Fig. 1

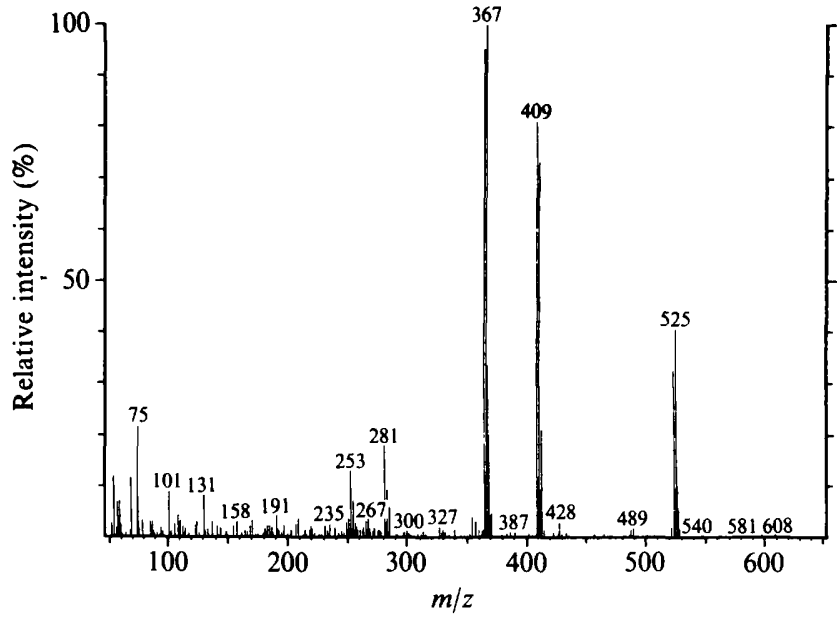

Fig. 2

Fig. 1. Mass spectrum of the Diels-Alder adducts of C16:1w5.

Fig. 2. Mass spectrum of the Diels-Alder adducts of C18:1w9.

Table 1. Fatty acid composition of strain Inp after growth at different temperatures

The composition is expressed as a weight percentage of the total fatty acids. The results presented are means of two experiments at each temperature; values in parentheses represent $\pm 1 \mathrm{SD}$.

\begin{tabular}{|c|c|c|c|}
\hline \multirow[b]{2}{*}{ Fatty acid } & \multirow[b]{2}{*}{ Growth temp. $\left({ }^{\circ} \mathrm{C}\right)$} & \multicolumn{2}{|c|}{ Fatty acid composition $(\%)$} \\
\hline & & 24 & 30 \\
\hline $14: 0$ & $0.53(0.55)$ & $1 \cdot 15(0.88)$ & $1.69(0.05)$ \\
\hline i1 $5: 0$ & $3.09(2.02)$ & $5.00(1.48)$ & $8.68(2.98)$ \\
\hline a15:0 & $0.29(0.07)$ & $0.16(0.21)$ & $0.93(1.30)$ \\
\hline $15: 0$ & $0.49(0.08)$ & $0.26(0.36)$ & $0.25(0.35)$ \\
\hline $16: 0$ & $11.96(2.97)$ & $14.92(4 \cdot 70)$ & $18.40(1.85)$ \\
\hline $16: 1 w 9$ & $3.03(0.70)$ & $1.58(2.23)$ & $0.03(0.04)$ \\
\hline $16: 1 w 7$ & - & $0.41(0.57)$ & $0.70(0.98)$ \\
\hline $16: 1 w 5$ & $53.80(2.70)$ & $48 \cdot 10(0.33)$ & $49.01(0.00)$ \\
\hline Unknown & $1.00(1.42)$ & $0.39(0.55)$ & $1.26(1.74)$ \\
\hline Unknown & $0.49(0.21)$ & $0.06(0.08)$ & $0.10(0.15)$ \\
\hline $17: 0$ & $0.40(0.09)$ & $0.06(0.07)$ & $1.06(0.98)$ \\
\hline $18: 0$ & $2.74(1.00)$ & $2.50(0.96)$ & $4 \cdot 50(2 \cdot 18)$ \\
\hline $18: 1 w 9$ & $9.40(1.54)$ & $10.40(0.39)$ & $5.82(1.74)$ \\
\hline $18: 1 \mathrm{w} 7$ & $3.26(3.90)$ & $0.98(1.40)$ & $1.15(1.62)$ \\
\hline $18: 2 w 6$ & $8.72(2.51)$ & $11 \cdot 74(1 \cdot 10)$ & $4.69(1.96)$ \\
\hline $18: 3 w 3$ & $0.45(0.35)$ & $1.07(0.30)$ & $0 \cdot 14(0 \cdot 20)$ \\
\hline $\begin{array}{l}\text { Total fatty acid content } \\
{\left[\mu \mathrm{g}(\mathrm{mg} \text { protein })^{-1}\right] \ldots}\end{array}$ & $56 \cdot 6(4 \cdot 6)$ & $70 \cdot 8 \quad(5 \cdot 4)$ & $158(22)$ \\
\hline Percentage unsaturation & $78.2(1.8)$ & $74 \cdot 3 \quad(5 \cdot 5)$ & $61.5(3.7)$ \\
\hline Unsaturation index ${ }^{*} \ldots$ & $0.88(0.04)$ & $0.88(0.07)$ & $0.66(0.03)$ \\
\hline
\end{tabular}

* Unsaturation index $=[(\%$ monounsaturates $)+2(\%$ diunsaturates $)+3(\%$ triunsaturates $)] / 100$.

C18:1w9 Diels-Alder adducts confirmed unequivocally the identification of the two main monounsaturated fatty acids in strain Inp (Figs. 1 and 2).

\section{Effect of temperature}

As shown in Table 1, C16:1w5 was the major fatty acid found under all conditions, ranging from $48 \cdot 1$ to $67 \cdot 7 \%$ of the total fatty acid content. Palmitic acid (C16:0) also formed a significant fraction of the total. Oleic acid (C18:1w9), and linoleic acid (C18:2w6) were next in order of abundance. The PUFAs linoleic (C18:2w6) and linolenic acid (C18:3w3) ranged from 4.7 to $11.7 \%$ and 0.1 to $1.1 \%$ respectively. The degree of unsaturation, measured as percentage unsaturation and unsaturation index, tended to decrease with increasing temperature (Table 1). 
Table 2. Fatty acid composition of strain Inp after growth at different salinities on starch as carbon source

The composition is expressed as a weight percentage of the total fatty acids. The results presented are means of three experiments at each salinity; values in parentheses represent $\pm 1 \mathrm{SD}$.

\begin{tabular}{|c|c|c|c|c|}
\hline \multirow[b]{2}{*}{ Fatty acid } & \multirow[b]{2}{*}{ Salinity (p.p.t.) } & \multicolumn{3}{|c|}{ Fatty acid composition $(\%)$} \\
\hline & & 30 & 45 & 60 \\
\hline $14: 0$ & $1.00(0 \cdot 26)$ & $0.69(0 \cdot 16)$ & $0 \cdot 67(0 \cdot 19)$ & $0 \cdot 60(0 \cdot 20)$ \\
\hline i1 5:0 & $9 \cdot 31(1 \cdot 70)$ & $3.72(0.50)$ & $3.26(0.57)$ & $1.27(0.41)$ \\
\hline al $5: 0$ & $2 \cdot 14(1 \cdot 50)$ & $2 \cdot 76(0.50)$ & $1.32(0 \cdot 53)$ & $0.33(0.36)$ \\
\hline $15: 0$ & $0.39(0.12)$ & $0.19(0.01)$ & $0.29(0.30)$ & $0.22(0.09)$ \\
\hline $16: 0$ & $8 \cdot 57(2 \cdot 15)$ & $7 \cdot 22(2.01)$ & $9.99(2.23)$ & $10.40(3.63)$ \\
\hline $16: 1 w 9$ & $1.36(0.40)$ & $2 \cdot 26(1 \cdot 79)$ & $2 \cdot 14(2 \cdot 33)$ & $2 \cdot 60(2 \cdot 27)$ \\
\hline $16: 1 w 7$ & $2 \cdot 56(2 \cdot 23)$ & $5 \cdot 22(2 \cdot 96)$ & $1.50(1.01)$ & $5 \cdot 12(3 \cdot 70)$ \\
\hline $16: 1 w 5$ & $65 \cdot 30(2 \cdot 62)$ & $69.00(1 \cdot 10)$ & $44.07(5 \cdot 55)$ & $19 \cdot 01(2 \cdot 88)$ \\
\hline Unknown & $0.32(0.55)$ & - & $0 \cdot 21(0 \cdot 38)$ & $0.23(0.39)$ \\
\hline Unknown & $0 \cdot 20(0 \cdot 34)$ & $0.23(0 \cdot 28)$ & $0.05(0.09)$ & - \\
\hline $17: 0$ & - & - & $0.08(0.14)$ & $0.44(0.38)$ \\
\hline $18: 0$ & $0 \cdot 39(0 \cdot 14)$ & $0.26(0.08)$ & $1.84(0.88)$ & $3.52(1.74)$ \\
\hline $18: 1 w 9$ & $2.68(0.29)$ & $2.09(1.07)$ & $13.88(4 \cdot 13)$ & $26.70(3.06)$ \\
\hline $18: 1 w 7$ & $0.55(0.05)$ & $0.73(0.24)$ & $6 \cdot 38(2 \cdot 14)$ & $6.30(1.71)$ \\
\hline $18: 2 w 6$ & $2.23(0.58)$ & $2.30(0.93)$ & $11.44(0.88)$ & $20.45(3.90)$ \\
\hline $18: 3 w 3$ & $0 \cdot 31(0.09)$ & $0.20(0.08)$ & $0.57(0.41)$ & $1.90(0.70)$ \\
\hline $\begin{array}{l}\text { Total fatty acid content } \\
{\left[\mu \mathrm{g}(\mathrm{mg} \text { protein })^{-1}\right] \ldots}\end{array}$ & $119 \cdot 6(10 \cdot 0)$ & $81 \cdot 28(23 \cdot 0)$ & $38 \cdot 5(10 \cdot 3)$ & $31.6(3.08)$ \\
\hline
\end{tabular}

Table 3. Fatty acid composition of strain Inp after growth at different salinities on 1/2-ZoBell medium

The composition is expressed as a weight percentage of the total fatty acids. The results presented are means of three experiments at each salinity; values in parentheses represent \pm 1 SD.

\begin{tabular}{|c|c|c|c|c|}
\hline \multirow[b]{2}{*}{ Fatty acid } & \multirow[b]{2}{*}{ Salinity (p.p.t.) . . 30} & \multicolumn{3}{|c|}{ Fatty acid composition $(\%)$} \\
\hline & & 45 & 60 & 120 \\
\hline $14: 0$ & $1.18(0.06)$ & $1.25(0.04)$ & $1.54(0.22)$ & $0.79(0.08)$ \\
\hline i1 $5: 0$ & $17.67(0.96)$ & $20.95(1.58)$ & $14 \cdot 20(1 \cdot 40)$ & $0.98(0.34)$ \\
\hline a $15: 0$ & $0.29(0.07)$ & $0.33(0 \cdot 10)$ & $0.20(0.11)$ & $0 \cdot 10(0 \cdot 10)$ \\
\hline $15: 0$ & $0.67(0.00)$ & $0.58(0.04)$ & $0.55(0.03)$ & $0 \cdot 11(0 \cdot 10)$ \\
\hline $15: 1^{*}$ & $1.93(1.72)$ & $1 \cdot 38(0 \cdot 12)$ & $0.72(0.08)$ & $0 \cdot 14(0.13)$ \\
\hline $16: 0$ & $4 \cdot 18(0.40)$ & $4 \cdot 11(1 \cdot 58)$ & $11.80(0.61)$ & $22.99(1.54)$ \\
\hline $16: 1 w 9$ & $0.87(0.37)$ & $1 \cdot 31(0.68)$ & $1.58(1.61)$ & $0 \cdot 19(0 \cdot 16)$ \\
\hline $16: 1 w 7$ & $0.37(0.21)$ & $0.15(0.25)$ & $0.22(0.22)$ & $0.35(0.31)$ \\
\hline $16: 1 \mathrm{w} 5$ & $55.49(2.50)$ & $49.90(2.92)$ & $53.79(2.64)$ & $4.75(2.69)$ \\
\hline Unknown & $0.44(0.03)$ & $0.24(0.09)$ & $0.14(0.05)$ & - \\
\hline Unknown & $0.81(0.02)$ & $1.57(0 \cdot 10)$ & $1.56(0 \cdot 11)$ & - \\
\hline Unknown & $0.94(0.04)$ & $0.86(0.18)$ & $0.27(0.03)$ & $0.08(0.14)$ \\
\hline $17: 0$ & $0.09(0.09)$ & $0.15(0.08)$ & $0.20(0.02)$ & $0.17(0.15)$ \\
\hline $18: 0$ & $0.78(0 \cdot 12)$ & $1.08(0.58)$ & $1.50(0.28)$ & $5.68(0.41)$ \\
\hline $18: 1 w 9 c$ & $5.88(1 \cdot 10)$ & $6.04(0.92)$ & $4.57(0.42)$ & $27 \cdot 14(4 \cdot 17)$ \\
\hline $18: 1 w 9 t$ & $0.81(0.27)$ & $0.95(0.22)$ & $0.70(0 \cdot 11)$ & $4 \cdot 16(0 \cdot 30)$ \\
\hline $18: 1 w 7$ & $0.66(0.33)$ & $0.80(0 \cdot 11)$ & $0.47(0.05)$ & $3.53(0.64)$ \\
\hline $18: 2 w 6$ & $5.06(1.09)$ & $4.91(0.53)$ & $3.63(0 \cdot 10)$ & $22.35(3.52)$ \\
\hline $18: 3 w 3$ & $0.47(0.09)$ & $0.47(0.10)$ & $0.70(0.11)$ & $2.01(0.50)$ \\
\hline $\begin{array}{l}\text { Total fatty acid content } \\
{\left[\mu \mathrm{g}(\mathrm{mg} \text { protein })^{-1}\right] \ldots}\end{array}$ & $56.7(17.9)$ & $34 \cdot 7(2 \cdot 50)$ & $30.9(9 \cdot 66)$ & $7.7(0.02)$ \\
\hline
\end{tabular}

* Double bond position not determined. 
Table 4. Fatty acid composition of strain Inp after growth on different carbon sources

The composition is expressed as a weight percentage of the total fatty acids. The results presented are means of three experiments (for Casamino acids, Tween 80 , glycerol, glucose and starch) or of two experiments (for lactose and gluconate); values in parentheses represent \pm 1 SD.

\begin{tabular}{|c|c|c|c|c|c|c|c|c|}
\hline \multirow[b]{2}{*}{ Fatty acid } & \multirow[b]{2}{*}{ Carbon source } & \multicolumn{7}{|c|}{ Fatty acid composition $(\%)$} \\
\hline & & Casamino acids & Tween 80 & Glycerol & Glucose & Starch & Lactose & Gluconate \\
\hline $14: 0$ & & $1.09(0.04)$ & $3.30(0.49)$ & $1.27(0.09)$ & $0.55(0 \cdot 02)$ & $1 \cdot 76(0 \cdot 23)$ & $0.54(0.00)$ & $1 \cdot 18(0 \cdot 06)$ \\
\hline i15:0 & & $12 \cdot 47(1 \cdot 24)$ & $3 \cdot 17(0 \cdot 45)$ & $10 \cdot 81(1.42)$ & $3.34(0 \cdot 37)$ & $8 \cdot 5(0.92)$ & $3 \cdot 34(0 \cdot 68)$ & $8 \cdot 24(0 \cdot 36)$ \\
\hline a $15: 0$ & & $0.52(0.16)$ & $0.29(0.01)$ & $0.65(0.15)$ & $0 \cdot 11(0 \cdot 1)$ & $0.78(0.33)$ & $0 \cdot 16(0.05)$ & $1 \cdot 37(0 \cdot 60)$ \\
\hline $15: 0$ & & $0.66(0.03)$ & $0.78(0.08)$ & $1.00(0 \cdot 26)$ & $\operatorname{tr}$ & $0.60(0.05)$ & $0.19(0.05)$ & $2 \cdot 40(0.55)$ \\
\hline $15: 1^{*}$ & & $0.68(0.01)$ & $0 \cdot 20(0.20)$ & $0.75(0.32)$ & $0 \cdot 11(0 \cdot 19)$ & $0 \cdot 30(0 \cdot 04)$ & - & $1.05(0 \cdot 10)$ \\
\hline $16: 0$ & & $6.43(0 \cdot 10)$ & $19 \cdot 17(2 \cdot 70)$ & $7.69(0.78)$ & $18.02(2 \cdot 26)$ & $13 \cdot 77(2 \cdot 47)$ & $20 \cdot 40(0.23)$ & $12.42(1.07)$ \\
\hline $16: 1 w 9$ & & $2.86(1.49)$ & $1.44(0 \cdot 18)$ & $1.55(0.60)$ & $0.65(0.27)$ & - & $0.13(0.18)$ & $3 \cdot 10(2 \cdot 25)$ \\
\hline $16: 1 \mathrm{w} 7$ & & $0.50(0 \cdot 20)$ & $4.60(0 \cdot 37)$ & $0.48(0 \cdot 10)$ & $0 \cdot 11(0 \cdot 19)$ & $3.48(1.92)$ & $0.23(0.18)$ & - \\
\hline $16: 1 \mathrm{w} 5$ & & $35 \cdot 18(1.80)$ & $17.90(3.94)$ & $34.61(0.72)$ & $30 \cdot 11(2.5)$ & $60 \cdot 15(2 \cdot 85)$ & $59.94(2.56)$ & $57.62(2.32)$ \\
\hline Unknown & & $1.79(0.54)$ & $1.02(0.22)$ & $0.65(0.27)$ & $0.51(0.07)$ & $0.53(0.47)$ & - & $0.35(0.02)$ \\
\hline Unknown & & $0.99(0 \cdot 18)$ & $0.08(0.13)$ & $1.00(0.71)$ & - & $0.51(0.11)$ & - & $1.51(0.12)$ \\
\hline Unknown & & $0.74(0.07)$ & $0.50(0.07)$ & $0.80(0.41)$ & - & $0.30(0.07)$ & - & $0.47(0.08)$ \\
\hline $\mathrm{i} 17: 0$ & & - & - & $0.27(0.00)$ & - & - & - & $0.44(0.10)$ \\
\hline a 17:0 & & $0 \cdot 14(0 \cdot 12)$ & - & - & - & - & - & - \\
\hline $17: 0$ & & $0 \cdot 17(0 \cdot 16)$ & $0.44(0.10)$ & $0.03(0.06)$ & $0.07(0 \cdot 11)$ & $0.08(0.13)$ & - & - \\
\hline $18: 0$ & & $1.82(0.09)$ & $4.65(1.97)$ & $1.88(0.40)$ & $3 \cdot 23(1 \cdot 11)$ & $0.78(0.17)$ & $1.08(0.25)$ & $0.83(0.08)$ \\
\hline $18: 1 w 9 c$ & & $12 \cdot 13(1.06)$ & $29.03(3.96)$ & $14.92(2.80)$ & $16.08(1 \cdot 16)$ & $1.72(1.18)$ & $4.40(1 \cdot 77)$ & $3.31(0.12)$ \\
\hline $18: 1 w 9 t$ & & $1.93(0.07)$ & - & $1.98(0.34)$ & $2.25(0.89)$ & - & $0.72(0.27)$ & $0.54(0.02)$ \\
\hline $18: 1 w 7$ & & $1.52(0.17)$ & $4.02(0.86)$ & $1.97(0.29)$ & $2.60(0.40)$ & $0 \cdot 17(0.07)$ & $0.61(0.20)$ & $0.51(0.00)$ \\
\hline $18: 2 w 6$ & & $10.53(0.17)$ & $1.42(0.25)$ & $12.07(1.47)$ & $17.77(1.26)$ & $1 \cdot 14(0.70)$ & $2 \cdot 77(0 \cdot 10)$ & $3.11(0.25)$ \\
\hline $18: 3 w 3$ & & $0.97(0.08)$ & - & $1 \cdot 14(0 \cdot 15)$ & $2.25(0.89)$ & $0.22(0.03)$ & $0.22(0.05)$ & $0.24(0.07)$ \\
\hline $\begin{array}{l}\text { Total fatty acid content } \\
{\left[\mu \mathrm{g}(\mathrm{mg} \text { protein })^{-1}\right] \ldots}\end{array}$ & & $40 \cdot 0(6 \cdot 24)$ & $43 \cdot 6(15 \cdot 2)$ & $64 \cdot 8(10 \cdot 1)$ & $43.9(0 \cdot 50)$ & $78 \cdot 2(3 \cdot 50)$ & $64 \cdot 5(1 \cdot 36)$ & $52 \cdot 8(13 \cdot 1)$ \\
\hline
\end{tabular}

* Double bond position not determined.

\section{Effect of salinity}

Increase in salinity was associated with a marked decrease in the total fatty acid content per $\mathrm{mg}$ cell protein (Tables 2 and 3). Both $\mathrm{iC} 15: 0$ and $\mathrm{C16}: 1 \mathrm{w} 5$ decreased markedly as salinity increased, while $\mathrm{C} 18: 1 \mathrm{w} 9$ and PUFAs increased. Linoleic and linolenic acid ranged from $2 \cdot 2$ to $22 \cdot 4 \%$ and $0 \cdot 2$ to $2 \cdot 0 \%$ respectively. Analysis of variance showed that both the proportions and the concentrations of the major fatty acids were significantly different over the range of salinities tested $(P>0 \cdot 1)$. Increasing the salinity from 30 to 120 p.p.t. in $1 / 2-Z$ oBell medium resulted in a marked decrease in $\mathrm{iC} 15: 0$ with a concomitant increase in $\mathrm{C16:0}$. The percentage of C16:1 w5, the major fatty acid in strain Inp, was constant at salinities from 30 to 60 p.p.t., but at 120 p.p.t. it decreased from about $60 \%$ to $4 \%$, whereas both oleic acid and PUFAs increased markedly.

\section{Effect of carbon source}

The highest concentration of fatty acid per $\mathrm{mg}$ cell protein was found in cells grown on starch (Table 4) followed by cells grown on gluconate or glycerol.
Both the highest concentration per mg cell protein and the highest percentage of PUFAs were found in cells grown on glucose, glycerol or Casamino acids (Table 4). iC15:0, the main branched fatty acid present in strain Inp, was found in especially high concentrations in cells grown on Casamino acids. The concentration and proportion of $\mathrm{Cl} 6: 1 \mathrm{w} 5$ were inversely proportional to those of PUFAs. The fatty acid composition of strain Inp grown on Tween 80 was influenced by the presence of the dominant fatty acid in the growth medium.

\section{Discussion}

In general, the fatty acid composition of Flexibacter strain Inp resembles that found by Nichols et al. (1986) for several Flexibacter species. These authors found that iC15:0, C16:0 and MUFAs with carbon chain lengths of either 16 or 18 comprised the bulk of the fatty acids. The position of the double bond in the monounsaturates and the presence and relative importance of branched fatty acids varied between species. Amongst the species examined by these authors $F$. flexilis, which has C16:1w5 as its major fatty acid, is perhaps the most 
closely related to strain Inp. Reports of $\mathrm{C16:1w5}$ in micro-organisms are uncommon, although it has been found in Cytophaga hutchinsonii (Walker, 1969) and in F. polymorphus (Johns \& Perry, 1977). The differences in the proportions of the major fatty acids between $F$. flexilis and strain Inp could be due to differences in the composition of the growth media used. In their experiments, Nichols et al. (1986) grew F. flexilis in a proteinrich medium. It is known that branched fatty acids can be synthesized from branched amino acid precursors (Boulton \& Ratledge, 1985). In addition, $F$. flexilis is a fresh-water species. It is not uncommon to find differences in fatty acid composition between fresh-water and marine species of the same genus (Wood, 1974).

There is an apparent discrepancy in the fatty acid compositions of strain Inp as determined in experiments in which temperature or salinity were varied. This difference could be due to the different air/nitrogen bubbling rates used in the two types of experiment.

The drop in fatty acid yield per unit protein as salinity increased is similar to that found by Pugh et al. (1971), who suggested that a high salt concentration could inhibit fatty acid synthetase. It is interesting to note that whereas cells of strain Inp grown on $1 / 2-$ ZoBell or on starch medium contained similar concentrations of fatty acid per mg cell protein at 60 p.p.t. salinity, the proportion of PUFAs in cells grown on starch medium at 60 p.p.t. salinity was similar to that in cells grown on $1 / 2$ ZoBell at 120 p.p.t. This suggests that the possible inhibition of fatty acid synthesis by increasing salt concentration in strain Inp was not directly coupled to the stimulation of PUFAs by increasing salinity.

The fatty acid composition of strain Inp when fatty acids present in Tween 80 were used as the carbon source reflected the major fatty acid present in the medium. Analysis of Tween 80 showed that $80 \%$ of its total fatty acid was C18:1w9. The absence of PUFAs from strain Inp when using Tween 80 as carbon source could be due to repression of the fatty acid synthesis enzymes by the free fatty acids present in the culture medium. This occurs in many species of bacteria (Weeks \& Wakil, 1970; Nunn, 1986; Schweizer, 1989).

Of the major fatty acids found in strain Inp, C18:1w9, $\mathrm{C} 18: 2 \mathrm{w} 6$ and $\mathrm{C} 18: 3 \mathrm{w} 3$ are likely to be related by a common biosynthetic mechanism as is found in green algae and higher plants, namely the aerobic pathway for synthesis of unsaturated fatty acids (Harwood \& Russell, 1984). If strain Inp has only the aerobic pathway, then two desaturases would be required, one specific for the $\Delta 9$ carbon and another for the $\Delta 11$ carbon. The presence of two desaturases has been reported in some bacteria (Fulco, 1970, 1983). If two such enzymes are present in strain Inp, the $\Delta 11$ and $\Delta 9$ desaturases are almost exclusively specific for fatty acids with carbon chain lengths of 16 and 18 , respectively. Additionally, the product of elongation of C16:1w5 would be either C18:1w5 or C18:1w7, depending at which end the two carbon atoms are inserted, but it is mostly likely to be C18:1w5. Hence the oleic acid could not originate from $\mathrm{C} 16: 1 \mathrm{w} 5$, Therefore, it is reasonable to hypothesize that strain Inp possesses both the anaerobic and aerobic pathways for synthesis of unsaturated fatty acids. Although Scheuerbrand \& Bloch (1962) suggested that both pathways were mutually exclusive, more recently Wada et al. (1989) have demonstrated the presence of both pathways in a psychrotropic Pseudomonas.

The inverse relationship between the amounts in strain Inp of the two major fatty acids, C16:1w5 and C18:1w9, both of which were identified unequivocally by $\mathrm{GC}$ and $\mathrm{GC} / \mathrm{MS}$, can be explained in terms of a linked flux mechanism so that when one pathway is dominant the other is recessive, or vice versa.

\section{References}

BLIGH, E. G. \& DYER, W. J. (1959). A rapid method of lipid extraction and purification. Canadian Journal of Biochemistry and Physiology 39, 911-917.

Boulton, C. A. \& Ratledge, C. (1985). Biosynthesis of fatty acids and lipids. In Comprehensive Biotechnology, vol. 1, pp. 459-482. Edited by A. T. Bull \& H. Dalton. Oxford: Pergamon Press.

Delong, E. F. \& Yayanos, A. A. (1986). Biochemical function and ecological significance of novel bacterial lipids in deep-sea prokaryotes. Applied and Environmental Microbiology 51, 730-737.

Fautz, E., Rosenfelder, G. \& Grotjahn, L. (1979). Iso-branched 2and 3-hydroxy fatty acids as characteristic lipid constituents of some gliding bacteria. Journal of Bacteriology 140, 852-858.

Fulco, A. J. (1970). The biosynthesis of unsaturated fatty acids in bacilli. II. Temperature dependent biosynthesis of polyunsaturated fatty acids. Journal of Biological Chemistry 245, 2985-2990.

Fulco, A. J. (1983). Fatty acid metabolism in bacteria. Progress in Lipid Research 22, 133-160.

Hanson, R. S. \& Phillips, J. A. (1981). Chemical composition. In Manual of Methods for General Bacteriology, pp. 328-364. Edited by P. Gerhardt, R. G. E. Murray, R. N. Costilow, E. W. Nester, W. A. Wood, N. R. Krieg and G. B. Phillips. Washington: American Society for Microbiology.

HARWOOD, J. L. \& RuSSELL, N. J. (1984). Lipids in Plants and Microbes. London: Allen and Unwin.

IMHOFF, J. F. \& Rodriguez-VALERA, F. (1984). Betaine is the main compatible solute of halophilic eubacteria. Journal of Bacteriology 160, 478-479.

Johns, R. B. \& Perry, G. C. (1977). Lipids of the marine bacterium Flexibacter polymorphus. Archives of Microbiology 114, 267-271.

KATES, M. (1986a). Influence of salt concentration on membrane lipids of halophilic bacteria. FEMS Microbiology Reviews 39, 95-101.

KATES, M. (1986b). In Techniques in Lipidology. Isolation, analysis and Identification of Lipids, 2nd edn. Edited by R. H. Burdon \& P. H. van Knippenberg. Amsterdam: Elsevier.

Kawagushi, A. \& Seyama, Y. (1984). Thermal control of fatty acid synthetases in bacteria. In Membrane Fluidity, pp. 271-301. Edited by M. Kates and L. A. Manson. New York: Plenum Press.

KidWell, P. A. \& BiemanN, K. (1982). Determination of double bond position and geometry of olefins by mass spectrometry of their DielsAlder adducts. Analytical Chemistry 54, 2462-2465.

LARSSON, L. \& ODHAM, G. (1984). Injection principles in capillary gas chromatographic analysis of bacterial fatty acids. Journal of Microbiological Methods 3, 77-82. 
LE RUdulier, D. \& BouILLARD, L. (1983). Glycine betaine, an osmotic effector in Klebsiella pneumoniae and other members of the Enterobacteriaceae. Applied and Environmental Microbiology 46, 152159.

Le Rudulier, D., Bernard, T., Goas, G. \& Hamelin, J. (1984). Osmoregulation in Klebsiella pneumoniae: enhancement of anaerobic growth and nitrogen fixation under stress by proline betaine, -butyrobetaine and other related compounds. Canadian Journal of Microbiology 30, 299-305.

MARR, A. G. \& InGRAHAM, J. L. (1962). Effect of temperature on the composition of fatty acids in Escherichia coli. Journal of Bacteriology 84, 1260-1267.

MILLER, K. J. (1985). Effect of temperature and sodium chloride concentration on the phospholipid and fatty acid composition of a halotolerant Planococcus sp. Journal of Bacteriology 162, 263-270.

MiLleR, K. J. (1986). Effects of monovalent and divalent salts on the phospholipid and fatty acid composition of a halotolerant Planococcus sp. Applied and Environmental Microbiology 52, 580-582.

Monteoliva-Sanchez, M., Ferrer, M. R., Ramos-Cormenzana, A., Quesada, E. \& Monteoliva, M. (1988). Cellular fatty acid and composition of Deleya halophila: effect of growth temperature and salt concentration. Journal of General Microbiology 134, 199-203.

Moss, C. W., LamberT, M. A. \& Merwin, W. H. (1974). Comparison of rapid methods for analysis of bacterial fatty acids. Applied Microbiology 28, 80-85.

Nichols, P. D., ShaW, P. M. \& Johns, R. B. (1985). Determination of double bond position and geometry in monoenoic fatty acids from complex microbial and environmental samples by capillary GC-MS of their Diels-Alder adducts. Journal of Microbiological Methods 3, 311-329.

Nichols, P. D., Stulp, B. K., Jones, J. G. \& White, D. C. (1986). Comparison of fatty acid content and DNA homology of the filamentous gliding bacteria Vitreoscilla, Flexibacter, Filibacter. Archives of Microbiology 146, 1-6.

NuNN, W. D. (1986). Molecular view of fatty acid catabolism in Escherichia coli. Microbiological Reviews 50, 179-192.

Oxuyama, H. Yamada, R., Akamatsu, Y. \& Nojima, S. (1977). Regulation of membrane lipid synthesis in Escherichia coli after shifts in temperature. Biochemistry 16, 2668-2673.

OPPENHEIMER, C. H. \& ZoBelL, C. E. (1952). The growth and viability of sixty-three species of marine bacteria as influenced by hydrostatic pressure. Journal of Marine Research 11, 10-18.

Poen, E., Aufderheide, M., Diekmann, H. \& Kroppenstedt, R. H. (1984). Taxonomic studies on filamentous bacteria from sewage belonging to the Flavobacterium-Cytophaga complex. Archives of Microbiology 137, 295-301.
Pugh, E. L., Wassef, M. K. \& Kates, M. (1971). Inhibition of fatty acid synthetase in Halobacterium cutirubrum and Escherichia coli by high salt concentrations. Canadian Journal of Biochemistry 49, 923958.

ReICHENBACH, H. (1989). Genus Microscilla. In Bergey's Manual of Systematic Bacteriology, vol. 3, pp. 2071-2073. Edited by J. T. Staley, M. P. Bryant, N. Pfennig \& J. G. Holt. Baltimore: Williams \& Wilkins.

REICHENBACH, H. \& DWORKIN, M. (1981). Introduction to the gliding bacteria. In The Prokaryotes, vol. 1, pp. 315-327. Edited by M. P. Starr, H. Stolp, H. G. Truper, A. Balows \& H. G. Schlegel. Berlin: Springer-Verlag.

RILEY J. P. \& CHESTER, R. (1971). Introduction to Marine Chemistry, pp. 465. London: Academic Press.

Rose, A. H. (1989). Influence of the environment on microbial lipid composition. In Microbial Lipids, vol. 2, pp. 255-278. Edited by C. Ratledge \& S. C. Wilkinson. London: Academic Press.

Russell, N. J. \& KoGUT, M. (1985). Haloadaptation: salt sensing and cell-envelope changes. Microbiological Sciences 11, 345-350.

SHAw, N. (1974). Lipids composition as a guide to the classification of bacteria. Advances in Applied Microbiology 17, 63-108.

SCHEUERBRAND, G. \& BLOCH, K. (1962). Unsaturated fatty acids in microorganisms. Journal of Biological Chemistry 237, 2064-2068.

SCHWEIZER, E. (1989). Biosynthesis of fatty acids and related compounds. In Microbial Lipids, vol. 2, pp. 3-50. Edited by C. Ratledge \& S. C. Wilkinson. London: Academic Press.

Wada, M., Fuxunaga, N. \& SaSaKi, S. (1989). Mechanism of biosynthesis of unsaturated fatty acids in Pseudomonas sp. strain E-3, a psychrotropic bacterium. Journal of Bacteriology 171, 4267-4271.

WALKER, R. W. (1969). Cis-11-hexadecenoic acid from Cytophaga hutchinsonii. Lipids 14, 15-18.

WeEks, G. \& WAKIL, S. J. (1970). Studies on the control of fatty acid metabolism. II. The inhibition of fatty acid synthesis in Lactobacillus plantarum by exogenous fatty acid. Journal of Biological Chemistry 245, 1913-1921.

White, D. C., Davies, W. M., Nichels, J. S., King, J. D. \& Bobbie, R. J. (1979). Determination of the sedimentary microbial biomass by extractable lipid phosphate. Oecologia 45, 51-62.

Wirsen, C. O., Jannasch, H. W., Wakeham, S. G. \& Canuel, E. A. (1987). Membrane lipids of a psychrophilic and barophilic deep-sea bacteria. Current Microbiology 14, 319-322.

WooD, B. J. B. (1974). Fatty acids and saponificable lipids. Botanical Monographs 8, 236-265.

Yazawa, K., Araki, K., Watanable, K., Ishikawa, C., Inoue, A., Kondo, K., Watabe, S. \& Hashimoto, K. (1988). Eicosapentaenoic acid productivity of the bacteria isolated from fish intestines. Nippon Suisan Gakkaishi 54, 1835-1838 (in English). 